\title{
New Zealand made controlled release coated urea increases winter growth rates of Italian ryegrass with lower $\mathbf{N}$ leaching than uncoated urea
}

\author{
P.A. BISHOP ${ }^{1 *}$, H.Y. LIU ${ }^{2}$, M.J. HEDLEY ${ }^{1}$ and P. LOGANATHAN ${ }^{1}$ \\ ${ }^{I}$ Institute of Natural Resources, Massey University, \\ Palmerston North, New Zealand \\ ${ }^{2}$ Liaoning Academy of Agricultural Sciences, Shenyang, China \\ bishopresearch@slingshot.co.nz
}

\begin{abstract}
In a field trial the application of 5 and $7 \%$ polyurethane coated controlled release urea, $10 \%$ dicyanodiamide coated urea and three x 50 split urea (SU) applications at $150 \mathrm{~kg}$ $\mathrm{N} / \mathrm{ha}(150 \mathrm{~N})$ increased winter pasture dry matter (DM) production of Italian ryegrass over the June-September period by between 1666 to $2240 \mathrm{~kg} \mathrm{DM} / \mathrm{ha}$. These treatments also reduced nitrate leaching losses from 6.8 to $1 \mathrm{~kg} \mathrm{~N} /$ ha compared to urea (U). The polyurethane coated controlled release urea increased $\mathrm{N}$ utilisation from between $12-15 \mathrm{~kg} \mathrm{DM} / \mathrm{kg} \mathrm{N}$ for $\mathrm{N}$ applied as U, SU and dicyanodiamide coated urea (DCDU) treatments to between $22-24 \mathrm{~kg} \mathrm{DM} / \mathrm{kg} \mathrm{N}$ based on the $\mathrm{N}$ released from the 5UCU and 7UCU treatments, respectively over the initial 3 months.
\end{abstract}

Keywords: controlled release urea, nitrogen utilisation, pasture, ryegrass

\section{Introduction}

Increases in dairy stocking rates often result in a winter feed deficits which require either supplementary feed to be brought in, stock to be grazed off-farm or " $\mathrm{N}$ boosted" winter pasture growth, all of which incur additional costs. The application of $\mathrm{N}$ in winter is an effective means of increasing N-limited pasture growth, although this results in direct losses of $\mathrm{N}$ via leaching with winter drainage causing potential risk to ground water quality. More significantly, elevated herbage $\mathrm{N}$ contents shortly after $\mathrm{N}$ fertiliser application may result in highly concentrated urine $\mathrm{N}$ (Castillo et al. 2000) being returned to the pasture in patches and leached (Ball et al. 1979; Magesan et al. 1996; Ledgard et al. 1999; Di \& Cameron 2002). To combat these effects, $\mathrm{N}$ fertilisers are usually applied in split applications at rates of $25-50 \mathrm{~kg} \mathrm{~N} / \mathrm{ha} /$ month to limit direct leaching losses. Nitrification inhibitors such as DCD are also sometimes applied in autumn to prevent nitrification and leaching of returned urine $\mathrm{N}$ from grazing (Di \& Cameron 2004). Such practices, however, increase production cost in terms of a potential NZ\$100/t additional spreading charges for split applications, while DCD increases costs by NZ $\$ 80-160 /$ ha and results in higher $\mathrm{N}$ recovery from pasture (Di \& Cameron 2004) and thus higher urine $\mathrm{N}$ returns. An alternative to split applications is a single large application of coated controlled release urea, which may reduce direct leaching losses and lower peak herbage $\mathrm{N}$ levels and thus urine $\mathrm{N}$ returns to pasture.

To assess the effectiveness of different forms of winter $\mathrm{N}$ applications, laboratory manufactured polyurethanecoated urea at 5 and $7 \%$ coating levels (5 UCU and $7 \mathrm{UCU}), 10 \%$ DCD coated urea (DCDU), urea (U) and split applications of urea (SU) were trialled on a short rotation Italian ryegrass at application rates of 50 and $150 \mathrm{~kg} \mathrm{~N} / \mathrm{ha}$.

\section{Materials and Methods \\ Site}

The trial was located on Tokomaru silt loam (Pallic Soil) at the Moginie sheep farm block of Massey University, Palmerston North, New Zealand; the soil properties at this site are shown in Table 1. The trial paddock had been cultivated and resown with Italian ryegrass $\left(\right.$ Feast II $\left.{ }^{\circledR}\right)$ in March 2007. The climactic conditions over the trial period (Table 4) provided sufficient rainfall and soil temperatures to maintain growth.

\section{Design and treatments}

The five $\mathrm{N}$ treatments (U, 5UCU, 7UCU, SU, DCDU) were tested at the application rate of $150 \mathrm{~kg} \mathrm{~N} / \mathrm{ha}(150$ $\mathrm{N}$ ) and four (U, 5UCU, 7UCU, DCDU) at $50 \mathrm{~kg} \mathrm{~N} / \mathrm{ha}$ $(50 \mathrm{~N})$ plus a nil-N control treatment. The treatments were replicated three times and arranged in $50 \mathrm{~N}$ and 150 $\mathrm{N}$ complete randomised block designs. The trial area was fenced with electric wire to keep livestock away, mown to a height of $6 \mathrm{~cm}$ and 33 plots of $1 \mathrm{~m} \times 2 \mathrm{~m}$ were pegged out. The treatments were broadcast by hand on the 20 June 2007 with the SU treatment applied again at

Table 1 Soil properties at the trial site.

\begin{tabular}{cccccc}
\hline $\begin{array}{c}\text { Soil depth } \\
(\mathrm{cm})\end{array}$ & $\begin{array}{c}\text { Total C } \\
(\text { LOI) }(\%)\end{array}$ & $\begin{array}{c}\text { Total N } \\
(\%)\end{array}$ & $\begin{array}{c}\text { Olsen P } \\
(\mathrm{mg} / \mathrm{kg})\end{array}$ & $\begin{array}{c}\mathrm{pH}(1: 2.5 \mathrm{w} / \mathrm{w} \\
\text { soil:water })\end{array}$ & $\begin{array}{c}\text { Bulk density } \\
\left(\mathrm{kg} / \mathrm{m}^{3}\right)\end{array}$ \\
\hline $0-10$ & $6.5-8.8$ & $0.27-0.35$ & $54-75$ & 5.6 & $1190-1250$ \\
\hline
\end{tabular}


Table 2 (a) Cumulative additional DM (cumulative treatment DM minus cumulative Nil-N control DM (b)) in kg $\mathrm{DM} / \mathrm{ha}$ for 50 and $150 \mathrm{~kg} \mathrm{~N} / \mathrm{ha}$ treatments on different harvest dates.

\begin{tabular}{lccccc}
\hline Treatments & $22 / 07 / 2007$ & $22 / 08 / 2007$ & $21 / 09 / 2007$ & $23 / 10 / 2007^{*}$ & $19 / 11 / 2007$ \\
\hline (a) Additional DM & & & & & \\
150 U & 522 & 1515 & 2288 & 2757 & 2286 \\
150 DCDU & 290 & 1199 & 1955 & 2009 & 1700 \\
150 5UCU & 477 & 1244 & 2009 & 2477 & 2291 \\
150 7UCU & 504 & 1079 & 1666 & 2065 & 2093 \\
150 SU & 309 & 1157 & 2240 & 2995 & 2723 \\
50 U & 344 & 747 & 953 & 1057 & 962 \\
50 DCDU & 295 & 764 & 1121 & 1319 & 1188 \\
50 5UCU & 232 & 598 & 1073 & 1397 & 1572 \\
50 7UCU & 141 & 492 & 857 & 1060 & 1075 \\
LSD 150 & 283 & 570 & 767 & 1125 & 1411 \\
LSD 50 & 138 & 326 & 525 & 859 & 984 \\
(b) DM for Nil only & & & & & \\
Control & 853 & 1556 & 2491 & 3380 & 4540 \\
s.d. & 98 & 349 & 583 & 886 & 1180 \\
\hline * Estimated harvest & \multicolumn{5}{r}{} \\
\hline
\end{tabular}

$50 \mathrm{~N}$ immediately following each of the next two harvests. The plots were mown on a monthly basis to measure dry matter (DM) and herbage $\mathrm{N}$ content, starting on 22 July. The amount of nitrate leached was calculated based on the nitrate concentration measured in soil solution collected from ceramic suction cup lysimeters positioned at the base of the cultivation zone $(25 \mathrm{~cm})$, in duplicate plots of the $150 \mathrm{~kg} \mathrm{~N} / \mathrm{ha}$ treatments, following significant rainfall ( $>10 \mathrm{~mm} /$ day). The total estimated drainage was calculated based on climatic data from NIWA/ AgResearch.

\section{Statistics}

The variance associated with treatment means was analysed in SAS software and estimates of the least significant difference (LSD) between treatments were reported at a confidence level of $95 \%$ for individual $50 \mathrm{~N}$ and $150 \mathrm{~N}$ treatments.

\section{Results and Discussion}

The trial progressed well until just prior to the October harvest when lambs broke through the surrounding electric fence and grazed the plots. The lost data were able to be modelled using factor analysis of the previous and the subsequent harvest using Minitab statistical software, which revealed a strong correlation $\left(\mathrm{R}^{2}=0.92\right)$ between DM produced, $\mathrm{N}$ uptake and solar radiation (Equation 1). The plot $\mathrm{N}$ uptake trends were also analysed allowing the October $\mathrm{N}$ uptake to be estimated. Equation 1 models the DM response based on the natural log of the solar radiation in $\mathrm{MJ} / \mathrm{m}^{2} /$ day and nitrogen uptake in $\mathrm{kg} \mathrm{N} / \mathrm{ha} /$ day.

$D M(\mathrm{~kg} / \mathrm{ha} /$ day $)=-7.18+19.9 \ln ($ solar radiation $)+$

$$
30.3 \ln \text { ( } N \text { uptake rate) (1) }
$$

Due to the uncertainty in these data the cumulative yield results are taken at the third harvest (September), while the October and November harvest are analysed individually.

\section{Dry matter}

The cumulative additional dry matter production (Table 2a) was calculated as the cumulative DM yield (data not shown) minus cumulative nil-N control DM yield (Table 2b). Over the first 3 months (column 21/09/2007 in Table 2a) for the $50 \mathrm{~N}$ treatments this ranged from 857 to 1121 $\mathrm{kg}$ of additional $\mathrm{DM} / \mathrm{ha}$ with no significant differences between treatments. Following the third month, a small increase in growth rate was obtained in October (modelled) followed by a significant (LSD P $=0.05,141$ $\mathrm{kg} \mathrm{DM} / \mathrm{ha}$ ) decrease in DM production relative to control (nil-N) in November for the 7UCU, U and DCDU treatments (-207,-322 and $-350 \mathrm{~kg} \mathrm{DM} /$ ha respectively). The negative growth response was suspected to be a result of suppressed $\mathrm{N}$ mineralisation/fixation in these treatments of 4 to $5 \mathrm{~kg} \mathrm{~N} / \mathrm{ha}$ over this month (calculated from the plant and soil $\mathrm{N}$ differences between the control and treatments) and the stalling of $\mathrm{N}$ release from the 7UCU due to low surface soil moisture.

At the higher rate of $150 \mathrm{~N}$, the cumulative additional DM production increased significantly over the initial 3 months to between 1666 and $2288 \mathrm{~kg} \mathrm{DM} / \mathrm{ha}$ (column $21 / 09 / 2007$, Table 2a) with no significant difference between $\mathrm{N}$ treatments. The trends followed similar patterns to the lower $\mathrm{N}$ rate treatments. The SU treatment $(3 \times 50 \mathrm{~N})$ continued to increase production over the 3 months. The estimated peak additional accumulated yield occurred in October (modelled) and ranged between 2009 to $2995 \mathrm{~kg}$ with no significant difference between N treatments. At the last harvest in November, DM yields on the 5UCU, SU, DCDU and U treatments were -185, $-308,-393$ and $-471 \mathrm{~kg} \mathrm{DM} / \mathrm{ha}$ lower than the control (single harvest LSD P $=0.05,145 \mathrm{~kg} \mathrm{DM} / \mathrm{ha}$ ) whereas 
Table 3 (a) Additional herbage $\mathrm{N}$ recovered from treatments (treatment minus nil- $\mathrm{N}$ control (b)) $(\mathrm{kg} \mathrm{N} / \mathrm{ha}$ ) on different harvest dates after $\mathrm{N}$ applications at 50 and $150 \mathrm{~kg} / \mathrm{ha}$.

\begin{tabular}{|c|c|c|c|c|c|}
\hline Treatments & $22 / 07 / 2007$ & $22 / 08 / 2007$ & $21 / 09 / 2007$ & $23 / 10 / 2007^{*}$ & $19 / 11 / 2007$ \\
\hline \multicolumn{6}{|c|}{ (a) Additional $\mathrm{N}$} \\
\hline $150 \mathrm{U}$ & 35 & 46 & 22 & 7 & -7 \\
\hline $150 \mathrm{DCDU}$ & 20 & 42 & 22 & 11 & -4 \\
\hline $1505 \mathrm{UCU}$ & 26 & 32 & 23 & 11 & -1 \\
\hline 1507 UCU & 24 & 23 & 16 & 8 & 2 \\
\hline $150 \mathrm{SU}$ & 17 & 36 & 46 & 20 & -3 \\
\hline $50 \mathrm{U}$ & 16 & 8 & 4 & 2 & -4 \\
\hline 50 DCDU & 14 & 11 & 10 & 1 & -5 \\
\hline $505 U C U$ & 8 & 7 & 12 & 5 & 1 \\
\hline $507 \mathrm{UCU}$ & 6 & 7 & 9 & 3 & -2 \\
\hline LSD 150 & 7.0 & 5.3 & 3.0 & 2.3 & 1.2 \\
\hline LSD 50 & 7.3 & 7.3 & 5.2 & 4.4 & 3.3 \\
\hline \multicolumn{6}{|c|}{ (b) Herbage $\mathrm{N}$ in Nil- $\mathrm{N}$} \\
\hline Control & 33 & 20 & 19 & 19 & 18 \\
\hline s.d. & 6 & 8 & 5 & 5 & 6 \\
\hline
\end{tabular}

Table 4 Summary of climatic data over harvest periods from NIWAa and trial site ${ }^{b}$.

\begin{tabular}{lcccc}
\hline Period & $\begin{array}{c}\text { Total solar } \\
\text { radiation } \\
\left(\mathrm{MJ}^{\mathrm{a}} \mathrm{m}^{2}\right)\end{array}$ & $\begin{array}{c}\text { Mean daily } \\
\text { ground temp. } \\
\left({ }^{\circ} \mathrm{C}\right)\end{array}$ & $\begin{array}{c}\text { Rainfall } \\
(\mathrm{mm})\end{array}$ & $\begin{array}{c}\text { Drainage }^{\mathrm{a}} \\
(\mathrm{mm})\end{array}$ \\
\hline 20 Jun -22 Jul & 176 & 8.2 & 84.8 & 27.1 \\
22 Jul-22 Aug & 217 & 10.0 & 108.4 & 61.6 \\
22 Aug- Sept & 337 & 11.0 & 29.7 & 14.1 \\
21 Sept-23 Oct & 433 & 12.4 & 86.8 & 13.2 \\
23 Oct-19 Nov & 572 & 14.7 & 64.2 & 0 \\
\hline
\end{tabular}

the 7UCU treatment showed no significant difference from the control.

The controlled release coated urea products have shown similar DM production over the trial period with significantly lower negative growth effect in the November period.

\section{Nitrogen recovery}

The additional herbage $\mathrm{N}$ recovered (difference between treatment and nil-N) (Table 3a) above that in the control (Table 3b) peaked in August (the second harvest) for the $150 \mathrm{~N}$ treatments, U, DCDU and 5UCU, reflecting 79, 68 and $61 \%$ of the total $N$ recovered respectively. The utilisation of $\mathrm{N}$ to produce DM was, however, low over these months, due to short days and low solar radiation (Table 4), resulting in low $\mathrm{N}$ to DM conversion efficiency (c.f. Table 2). Nitrogen recovery peaked in the SU treatment in September (the third harvest) following the final application of urea, while the 7UCU produced an initial peak with a gradual reduction in rate over the trial.

In terms of cumulative percent $\mathrm{N}$ recovery (= cumulative $\mathrm{N}$ recovered $\mathrm{x} 100 / \mathrm{N}$ supplied), there was no significant difference between treatments at the $50 \mathrm{~N}$ rate, with $\mathrm{N}$ recoveries by November ranging between 42 to $66 \%$. At $150 \mathrm{~N}$, the $5 \mathrm{UCU}, \mathrm{DCDU}, \mathrm{U}$ and SU treatments had cumulative percent $\mathrm{N}$ recoveries between
61 to $77 \%$ with the $7 \mathrm{UCU}$ being significantly lower $(49 \%, \mathrm{P}<0.03)$ based on the quantity of $\mathrm{N}$ applied. The apparently low percent $\mathrm{N}$ recovery in the 7UCU treatment was due to $27 \%$ of the applied $N$ remaining unreleased from the coated granules at the completion of the trial.

The application of the DCDU, SU and U treatments at both rates showed significantly lower $\mathrm{N}$ recoveries at the November harvest than the control, resulting in significant losses in DM production relative to the control, 5UCU and 7UCU treatments. These results were amplified in the DM data, due to the rate of $\mathrm{N}$ to DM conversion during November of $59 \mathrm{~kg} \mathrm{DM} / \mathrm{kg} \mathrm{N}$ (based on harvest herbage $\mathrm{N}$ content). The release rate of the 5UCU and 7UCU appears to have stalled over the November due to dry surface conditions giving lower than expected $\mathrm{N}$ release/uptake and DM yields (soil moisture, data not shown).

\section{Drainage}

The application of urea using split applications, in the form of controlled release coated urea or as DCDU significantly reduced soil solution nitrate levels and estimated cumulative leaching losses at the application rate of $150 \mathrm{~N}$ (Fig. 1). During the initial drainage on 6/7/ 2007 the soil solution $\mathrm{N}$ concentrations were highly variable producing no significant difference between the 
Figure 1 Estimated nitrate-N leaching from $150 \mathrm{~kg} \mathrm{~N} / \mathrm{ha}$ treatments during drainage events. Vertical error bars indicate LSD $(P=0.05)$.

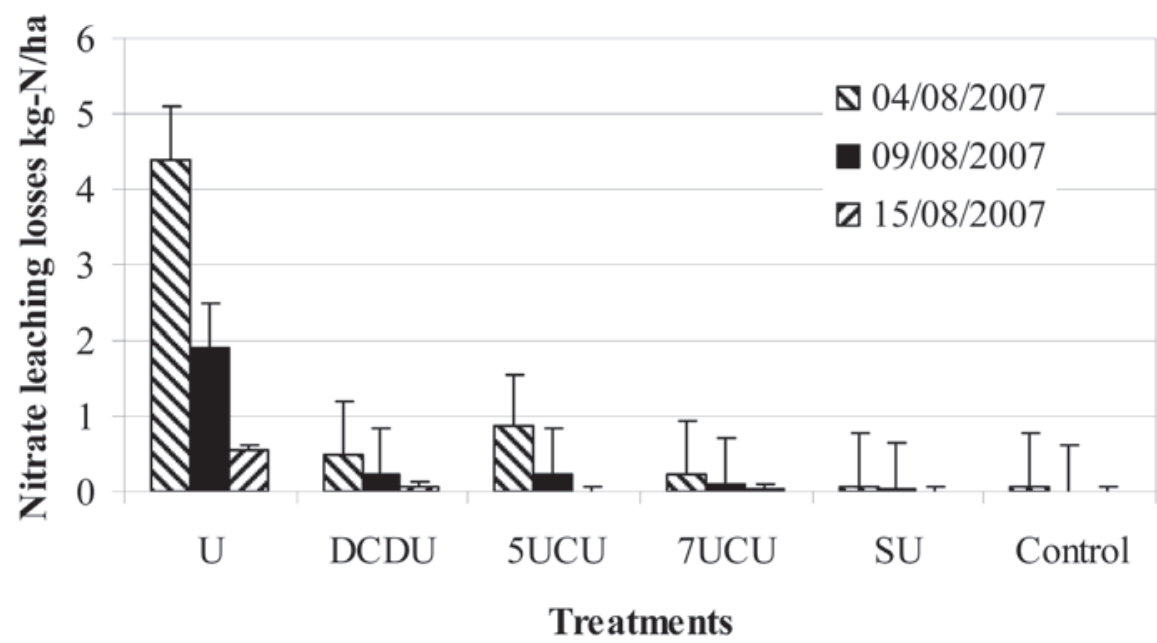

Figure 2 Monthly herbage $\mathrm{N}$ contents of pasture at harvest for $150 \mathrm{~N}$ treatments. Vertical bars indicate LSD $(P=0.05)$.

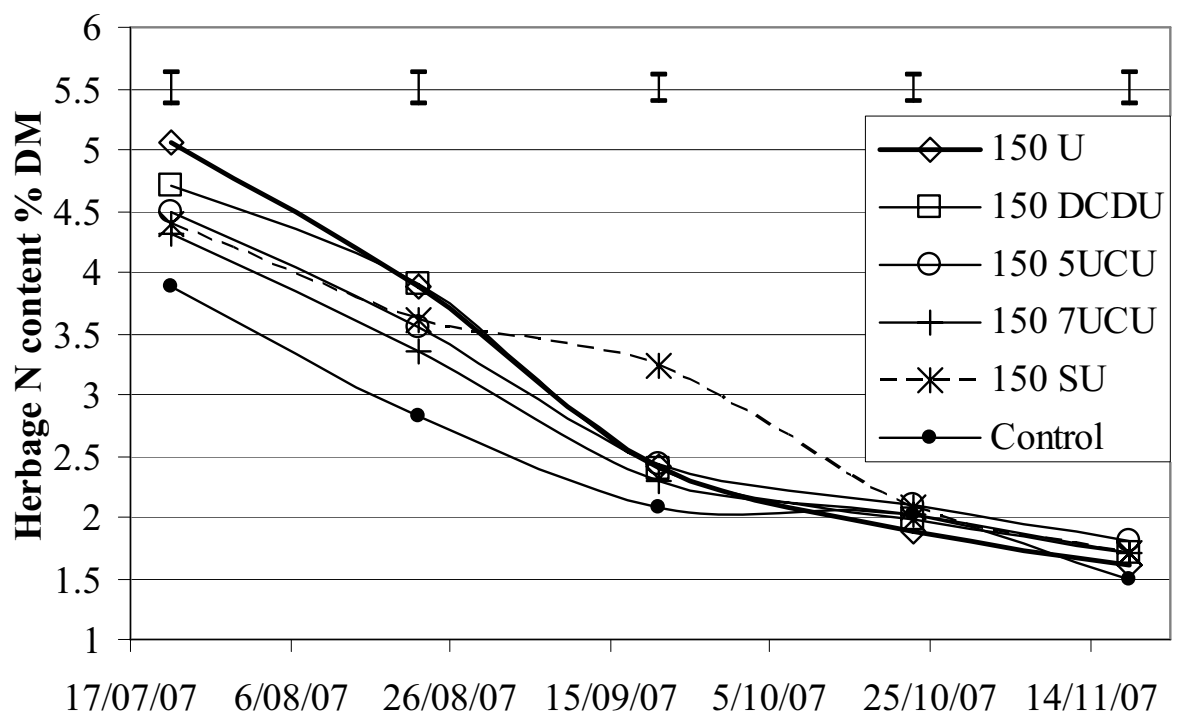

\section{Harvest Dates}

treatments and control. This initial nitrate-N leaching of $2.5 \pm 2.2 \mathrm{~kg} \mathrm{~N} / \mathrm{ha}$ resulted from initial cultivation as indicated by the analysis of pre-treatment core samples collected on 15/6/2007 that showed high levels of soil nitrate at the 15 to $25 \mathrm{~cm}$ depths. For this reason the initial drainage has been excluded from the data in Figure 1.

\section{Climatic conditions}

The climatic conditions (Table 4) over the trial period provided sufficient rainfall and soil temperatures to maintain growth over the 5 month period with the increasing day length and solar radiation increasing the potential effective conversion of $\mathrm{N}$ to DM from 22 to $59 \mathrm{~kg} \mathrm{DM} / \mathrm{kg} \mathrm{N}$ at a N uptake rate of $1 \mathrm{~kg} \mathrm{~N} / \mathrm{ha} /$ day.

\section{Nitrogen use efficiency}

The $\mathrm{N}$ use efficiency in terms of additional $\mathrm{kg} \mathrm{DM}$ produced per $\mathrm{kg}$ of $\mathrm{N}$ released into the pasture ranged 
between $12-15 \mathrm{~kg} \mathrm{DM} / \mathrm{kg} \mathrm{N}$ for both the 50 and $150 \mathrm{~N}$ rates applied as the U, SU and DCDU while the 5UCU and 7UCU treatments produced $\mathrm{N}$ use efficiencies of $22-24 \mathrm{~kg} \mathrm{DM} / \mathrm{kg} \mathrm{N}$ for both rates of $\mathrm{N}$ application over the initial 3 months based on the amounts of $\mathrm{N}$ released. At the $150 \mathrm{~N}$ rate, the $5 \mathrm{UCU}$ and $7 \mathrm{UCU}$ products released 90 and $72 \mathrm{~kg} \mathrm{~N} /$ ha respectively over the initial 3 months (based of release rate studies and soil temperature, data not shown) resulting in more efficient $(\mathrm{P}<0.0001)$ use of $\mathrm{N}$ to produce DM than the $150 \mathrm{~N}$ urea and DCDU treatments.

The $\mathrm{N}$ use efficiency is evident in the herbage $\mathrm{N}$ contents (Fig. 2) which were highest in winter in the "N boosted" pasture produced by the U and DCDU at 150 $\mathrm{N}$, while the 7UCU produced lower herbage $\mathrm{N}$ over the duration of the trial. The SU treatment initially produced lower herbage $\mathrm{N}$ compared with $150 \mathrm{U}$, but increased herbage $\mathrm{N}$ in September due to dry conditions prior to the harvest producing poor $\mathrm{N}$ conversion to $\mathrm{DM}$ and high $\mathrm{N}$ content. The increase in herbage $\mathrm{N}$ above $2.5 \%$ $\mathrm{N}$ will result in proportionally more $\mathrm{N}$ deposited as urine. In winter this raises the risk of increasing $\mathrm{N}$ leaching from urine patches.

\section{Conclusion}

Controlled-release coated urea offers the potential to increase the conversion of $\mathrm{N}$ to $\mathrm{DM}$ and reduce the proportion of herbage $\mathrm{N}$ leached from urine patches. Optimum $\mathrm{N}$ use efficiency from a controlled-release urea application requires wet conditions to allow surface incorporation of the products into the soil and sustained moisture over the growing period, making it well suited for use in irrigated pastures. Further work is required to improve the $\mathrm{N}$ release characteristics to reduce the initial release and increase the slower than optimum final release rate. The split application of urea or use of the nitrification inhibitor DCD is effective in preventing direct leaching of nitrate- $\mathrm{N}$ but has the potential to produce high herbage $\mathrm{N}$ levels resulting in the secondary loss of $\mathrm{N}$ via urine patches.

\section{REFERENCES}

Ball, R.; Keeney D.R.; Theobald, P.W.; Nes, P. 1979. Nitrogen balance in urine-affected areas of New Zealand pasture. Agronomy Journal 71: 309-314.

Castillo, A.R.; Kebreab, E.;Beever D.E.; France, J. 2000. A review of efficiency of nitrogen utilisation in lactating dairy cows and its relationship with environmental pollution. Journal of Animal and Feed Sciences 9: 1-32.

Di, H.J.; Cameron, K.C. 2002. Nitrate leaching and pasture production from nitrogen sources on shallow stoney soil under flood-irrigated dairy pasture. Australian Journal of Soil Research 40: 317-334.

Di, H.J.;Cameron, K.C. 2004. Treating grazed pasture soil with a nitrification inhibitor, eco- $\mathrm{n}^{\mathrm{TM}}$, to decrease nitrate leaching in deep sandy soil under spray irrigation - a lysimeter study. New Zealand Journal of Agricultural Research 47: 351-361.

Ledgard, S.F.; Penno, J.W.; Sprosen, M.S. 1999. Nitrogen inputs and losses from clover/grass pastures grazed by dairy cows, as affected by nitrogen fertilizer application. Journal of Agricultural Science 132: 215225.

Magesan, G.H.; White, R.E.; Scotter, D.R. 1996. Nitrate leaching from drained, sheep-grazed pasture. I. Experimental results and environmental implications. Australian Journal of Soil Research 34: 55-67. 